\title{
DINAMIKA LANSKAP KABUPATEN KETAPANG DAN KABUPATEN KAYONG UTARA TERHADAP PERUBAHAN INDEKS PEMBANGUNAN MANUSIA DAN IKLIM
}

\author{
(Landscape Dynamic of Ketapang District and Kayong Utara District towards to Human \\ Developing Index and Climate)
}

\author{
Darkono ${ }^{1}$, Hadi Susilo Arifin ${ }^{2}$, Ahyar Ismail ${ }^{3}$ \\ 1 Program Studi Ilmu Pengelolaan Sumberdaya Alam dan Lingkungan, Sekolah Pascasarjana, Institut \\ Pertanian Bogor, Kampus IPB Baranangsiang. \\ 2 Departemen Arsitektur Lanskap, Institut Pertanian Bogor, Kampus IPB Dramaga. \\ 3 Departemen Ekonomi Sumberdaya dan Lingkungan, Institut Pertanian Bogor, Kampus IPB Dramaga. \\ Email :darkono9@gmail.com
}

\begin{abstract}
The paper describes a landscape dynamic (Change Index-CI) of Ketapang and Kayong Utara Districs, West Kalimantan, in 1990-2018 and its correlation of peoples' welfare condition and environmental condition change. Land-based investment has increased sharply in the past 20 years. This condition influences landscape dynamic and climate condition. CI is identified through spatial and temporal analysis by calculating human intervention level to land cover. Meanwhile, the condition of peoples' welfare at sub-district level is measured from the district's Human Development Index (HDI) which is analyzed from CI. In this analysis, the HDI is considered a dependent variable and CI level as the independent variable. Landscape environmental condition uses information on annual average temperature of landscape.

The study applies simple regression method for the 2000, 2010 and 2018 HDIs with the CI of 1990-2000, 2000-2001 and 2010-2018 periods in 26 sub-districts. The results show that CI has positive correlation with the HDI of 0.086 regression coefficient value. It implies that there is significant correlation of the HDI and CI. The higher the CI value, the higher the HDI will increase. Thus, the regression result is the HDI $=60.103+0.086 C I$, with $<0.05$ value (significant). It means every growth by $1 \%$ at each sub-district, it will lead the rise of HDI by $0.086 \%$ at that sub-district. Meanwhile, the average of annual landscape temperature ascends along the growing CI. The temperature increases significantly by $0.95^{\circ} \mathrm{C}$ during $1990-2018$ periods following the massive land-based investment. On the other hand, prior to the massive land-based investment during 1985-1990, the temperature increase was $0.32^{\circ} \mathrm{C}$.
\end{abstract}

Keywords: Change Index, Environmental Condition, Oil Palm, Spatial, Temperature, Welfare

\begin{abstract}
Abstrak
Jurnal ini menggambarkan dinamika lanskap (Change Index - CI) Kabupaten Ketapang dan Kabupaten Kayong Utara, Provinsi Kalimantan Barat pada periode 1990 - 2018 kaitannya dengan kesejahteraan masyarakat dan perubahan kondisi lingkungan. Investasi berbasis lahan mengalami peningkatan secara signifikan dalam 20 tahun terakhir. Kondisi ini mempengaruhi dinamika lanskap dan kondisi iklim. CI dapat diidentifikasi dengan memperhitungkan tekanan manusia terhadap tutupan lahan baik secara spasial dan temporal. Sementara itu, kondisi kesejahteraan masyarakat pada wilayah administrasi kecamatan dihitung dihitung dari Indeks Pembangunan Manusia (IPM) wilayah Kabupaten yang dihasilkan dari analisis menggunakan CI. Pada Analisis ini, IPM merupakan variabel terikat dan indek CI merupakan variabel bebas. Kondisi lingkungan landskap menggunakan informasi suhu rata-rata tahunan.

Penelitian ini menggunakan metode regresi sederhana antara nilai IPM tahun 2000, 2010, dan 2018 dengan CI periode tahun 1990-2000, 2000-2001, dan 2010-2018 pada 26 wilayah kecamatan. Hasilnya menunjukkan korelasi positif dengan nilai koefisien regresi IPM sebesar 0.086. Ini berarti bahwa terdapat korelasi signifikan antara IPM dan CI. Kenaikan nilai CI akan
\end{abstract}


meningkatkan nilai IPM. Sehingga, regresi yang dihasilkan adalah IPM $=60.103+0.086 C I$, dengan nilai $<0.05$ yang berarti bahwa korelasinya sangat signifikan. Hal ini berarti bahwa setiap kenaikan CI sebesar $1 \%$ pada setiap kecamatan, maka ini akan meningkatkan nilai IPM sebesar $0.086 \%$ pada kecamatan tersebut. Sementara itu, suhu rata-rata tahunan pada lanskap mengalami kenaikan selama adanya peningkatan CI. Suhu pada lanskap meningkat drastis sebesar $0.95^{\circ} \mathrm{C}$ selama periode 1990-2018, hal ini sejalan dengan investasi berbasis lahan mengalami peningkatan secara massif. Sementara itu, sebelum investasi berbasis lahan dilakukan secara massif pada periode 1985-1990, kenaikan suhu sebesar $0.31^{\circ} \mathrm{C}$

Kata kunci: Change Index, Kelapa Sawit, Kesejahteraan, Kondisi lingkungan, Suhu, Spasial.

\section{PENDAHULUAN}

Laju perluasan kebun kelapa sawit di Kalimantan Barat dalam sepuluh tahun terakhir sejak tahun 2000 sangat cepat mencapai rata-rata $6,72 \%$ per tahun (KLHK, 2017). Hal ini mengakibatkan alih fungsi lahan dan hutan untuk memenuhi kebutuhan pembukaan kebun kelapa sawit juga meningkat. Perubahan fungsi lahan dan hutan menjadi kebun kelapa sawit ini telah menyebabkan hilang dan berkurangnya hutan sebagai sumber penghidupan masyarakat. Namun di sisi lain, perluasan kebun kelapa sawit juga memberikan dampak terhadap kesejahteraan masyarakat. Pengukuran kesejahteraan masyarakat pada lanskap salah satunya menggunakan indeks pembangunan manusia (IPM) (BPS, 2019). IPM setiap tahun dipublikasi oleh Badan Pusat Statistik (BPS) hanya sampai tingkat kabupaten. Hal ini karena pengukuran IPM didasari oleh besarnya alokasi anggaran belanja kabupaten dan bagaimana realisasinya serta luarannya terhadap kesejahteraan masyarakat kabupaten. Sementara itu, kesejahteraan masyarakat kabupaten merupakan akumulasi dari kondisi kesejahteraan masyarakat tingkat desa hingga kabupaten. Kesejahteraan pada setiap kecamatan berbeda-beda, dipengaruhi oleh pengelolaan sumberdaya alam dan kegiatan pembangunannya (BPS
2019). Maka, penelitian ini dilakukan untuk mengetahui tingkat IPM pada wilayah kecamatan.

Lanskap merupakan area lahan heterogen menyusun sebuah klaster interaksi ekosistem yang berulang pada bentuk yang sama pada setiap bagian (Forman \& Gordon 1986). Dinamika lanskap mengacu kepada proses evolusi lanskap, menelusuri keterkaitan antara manusia dan lingkungan (Wood \& Handley 2001). Dinamika lanskap merupakan interaksi antara dimensi ruang, waktu dan pembuatan keputusan manusia pada proses biofisik (Agarwal et al. 2002). Dinamika lanskap memiliki dua parameter kunci yaitu temporal (waktu) T, yang berkaitan dengan proses pemulihan dan parameter skala ruang (spatial) S, yang berkaitan dengan gangguan (kerusakan) lanskap (Turner et al. 1993).

Tingkat dinamika suatu lanskap (Change Index/CI) digunakan untuk mengetahui seberapa besar perubahan yang terjadi pada lanskap selama periode tertentu. CI sangat dipengaruhi oleh interaksi atau tekanan manusia terhadap sumberdaya alam (Käyhkö \& Skånes 2006). CI juga merepresentasikan kegiatan investasi berbasis lahan pada lanskap. Besarnya investasi berbasis lahan harus meningkatkan kesejahteraan masyarakat. IPM sebagai salah satu alat ukur untuk 
melihat kesejahteraan masyarakat belum mampu menunjukan nilainya hingga wilayah kecamatan. Padahal, investasi berbasis lahan lebih terlihat jelas keberadaannya di wilayah kecamatan.

Penelitian ini bertujuan untuk mengetahui kondisi dinamika lanskap pada periode 1990 hingga 2018 dan pengaruhnya terhadap perubahan kesejahteraan masyarakat dan perubahan kondisi lingkungan pada tingkat kecamatan. Kesejahteraan masyarakat pada lanskap diukur dengan menggunakan IPM, yang merupakan variabel terikat pada analisis ini, sedangkan kondisi lingkungan lanskap menggunakan informasi kondisi iklim sebelum dan sesudah investasi berbasis lahan dilakukan secara masif.

\section{METODE PENELITIAN}

\section{Waktu dan Lokasi Penelitian}

Penelitian di lapangan dilaksanakan pada bulan September - Desember 2018 yang meliputi pengambilan data di lapangan, pengolahan dan analisis data. Lokasi penelitian di lanskap Kabupaten Ketapang dan Kabupaten Kayong Utara dengan luas 3.443.766 Ha yang berada di Propinsi Kalimantan Barat. Lanskap ini memiliki beragam tipe ekosistem, mulai ekosistem pesisir di bagian barat, ekosistem hutan Dipterocarpaceae dataran rendah di Pegunungan Schwaner, ekosistem rawa gambut dibagian tengah, hingga ekosistem pegunungan di wilayah Taman Nasional Gunung Palung (MacKinnon et al. 1996).

\section{Jenis Data}

Dalam penelitian ini digunakan data spasial digital penutupan lahan tahun 1990 , 2000, 2010, dan 2018. Selain itu juga menggunakan hasil wawancara dengan ahli botani, dan ekologi mengenai tingkat gangguan manusia terhadap lahan. Data suhu rata-rata bulanan tahun 1985, 1987, 1990, 2000, 2010, dan 2018 bersumber dari Badan Meteorologi, Klimatologi dan Geofisika (BMKG). Data IPM dari BPS Kabupaten Ketapang dan Kabupaten Kayong Utara pada tahun 2000, 2010 dan tahun 2018. Data batas administrasi kecamatan di kedua kabupaten sebanyak 26 kecamatan bersumber dari BPS tahun 2013.

\section{Tahapan Penelitian}

\section{Mengetahui Dinamika Lanskap Kaitannya dengan IPM Pembobotan Tutupan Lahan}

Pembobotan data tutupan lahan lanskap tahun 1990, 2000, 2010, dan 2018 dilakukan berdasarkan besarnya pengaruh manusia terhadap perubahan tutupan lahan tersebut. Pada lanskap penelitian, data tutupan lahan tahun 2018 memiliki 20 kelas tutupan lahan, terdiri atas: Hutan Primer (Hp), Hutan Sekunder (Hs), Hutan Rawa Primer (Hrp), Hutan Rawa Sekunder (Hrs), Hutan Mangrove Sekunder (Hms), Hutan Tanaman (Ht), yang dikategorikan Hutan. Kemudian, Perkebunan (Pk), Pertanian Lahan Kering (Pt), Pertanian Lahan Kering Campur Semak (Pc), Belukar (B), Belukar Rawa (Br), Sawah (Sw), Lahan Terbuka (T), Pertambangan (Tb), Permukiman $(\mathrm{Pm})$, Transmigrasi (Tr), Bandara (Bdr), Tambak (Tm), Rawa (Rw), dan Badan Air (A) dikategorikan bukan hutan.

Berdasarkan pertimbangan 10 ahli yang memahami kondisi lanskap Kabupaten Ketapang dan Kabupaten Kayong Utara secara mendalam dan telah melakukan penelitian keanekaragaman hayati termasuk ekosistemnya. Para ahli tersebut memberi bobot mulai dari nilai 
satu untuk kelas tutupan lahan yang sangat kecil dipengaruhi oleh manusia hingga 20 untuk kelas yang sangat besar perubahannya dipengaruhi oleh manusia. Semakin tinggi pengaruh manusia terhadap perubahan tutupan lahan maka nilainya semakin besar begitu juga sebaliknya.

\section{Analisis Dinamika Lanskap}

Dinamika lanskap digunakan untuk mengetahui kondisi saat ini dan sebelumnya. Untuk mengukur dinamika lanskap, digunakan pendekatan change index (CI) atau indeks dinamika lanskap. CI didasarkan pada perbandingan klasifikasi tutupan lahan pada periode tertentu. Kelas tutupan lahan diberikan bobot yang nilainya berdasarkan pada pertimbangan ahli (expert judgement), nilai bobot mengindikasikan tingkat pengaruh manusia (human influence) terhadap setiap kelas tutupan lahan (Käyhkö \& Skånes 2006), dengan formula:

Change Index (indeks kedinamisan)

$$
\mathrm{CI}=\sum_{\substack{\mathrm{i}=1 \\ \text { dimana: }}}^{\mathrm{N}-1}\left|\mathrm{~T}_{\mathrm{i}}-\mathrm{T}_{\mathrm{i}+1}\right|
$$

CI : Change Index (Indeks perubahan/dinamika)

$\mathrm{N}$ : Lamanya periode perubahan

i : Tahun awal terjadinya perubahan

$\mathrm{T}$ : Waktu

CI merupakan nilai tingkat perbuahan penggunaan dan tutupan lahan (landuse and landcover changed) di setiap kecamatan pada lanskap. Rentang waktu yang digunakan (N) sejak 1990 hingga 2018, dibagi menjadi periode 1990-2000, 20002010, dan 2010-2018, sehingga menghasilkan tiga nilai CI.

\section{Mengetahui Indeks Pembangunan Manusia (IPM)}

IPM merupakan salah satu alat ukur pencapaian kualitas hidup suatu wilayah atau Negara (BPS, 2019). IPM digunakan sebagai gambaran kesejahteraan suatu wilayah. BPS hanya menghitung IPM sampai wilayah kabupaten, sehingga tingkat kesejahteraan masyarakat tingkat kecamatan tidak diukur. Komponen IPM terdiri dari tiga dimensi pokok, yaitu umur panjang dan hidup sehat (longevity), pengetahuan (knowledge), dan standar hidup layak. Kemudian, ketiga dimensi tersebut diturunkan menjadi empat indikator yaitu angka harapan hidup saat lahir $(\mathrm{AHH})$, angka melek huruf (AMH), gabungan angka partisipasi kasar (APK), dan produk domestik bruto (PDB) per kapita yang selanjutnya menjadi pendapatan nasional bruto atau gross national income (GNI) per kapita (BPS 2016).

$$
\begin{aligned}
& \text { IPM }=\frac{1}{3}\left[\mathrm{X}_{(1)}+\mathrm{X}_{(2)}+\mathrm{X}_{(3)}\right] \quad \ldots . .(2) \\
& \text { dimana: } \\
& \text { IPM } \quad \text { : Persentase indeks pembangunan } \\
& \text { manusia } \\
& \mathrm{X}(1) \text { : Indeks harapan hidup } \\
& \mathrm{X}(2): \text { Indeks pendidikan }=2 / 3 \text { (indeks melek } \\
& \quad \text { huruf /AMH) }+1 / 3 \text { (indeks rata- rata } \\
& \text { lama sekolah /APK) } \\
& \mathrm{X}(3) \text { : Indeks standar hidup layak }
\end{aligned}
$$

IPM dikategorikan menjadi empat, antara lain: IPM < 60\%: dikategorikan rendah; $60-70 \%$ : dikategorikan sedang;70$80 \%$ : dikategorikan tinggi; dan IPM $\geq$ $80 \%$ : dikategorikan sangat tinggi (BPS 2019). Nilai IPM yang digunakan adalah IPM pada 2000, 2010, dan 2018. IPM merupakan representasi hasil pembangunan yang dilaksanakan pada periode sebelumnya. IPM tahun 2000 merupakan hasil dari proses pembangunan dengan mengelola sumber daya alam pada 
periode sebelum 2000. Sehingga nilai CI penting untuk diketahui di setiap kecamatan, yang memberikan gambaran apakah dinamika lanskap memberikan dampak terhadap IPM.

\section{Penentuan Hubungan antara CI dengan IPM}

Mengetahui pengaruh dari dinamika lanskap (CI) Kabupaten Ketapang dan Kabupaten Kayong Utara terhadap indeks pembangunan manusia (IPM) dengan membuat persamaan regresi antara CI dengan IPM. Persamaan regresi yang digunakan yaitu $\mathrm{Y}=\mathrm{a}+\mathrm{bX}$, dimana $\mathrm{Y}$ adalah kondisi IPM sebagai variabel terikat dan X adalah CI sebagai variabel bebas. Untuk melihat korelasi antara IPM dan CI maka dicari koefisien korelasinya. Koefisien korelasi (r) yang semakin mendekati nilai satu maka korelasi antar kedua variabel semakin baik (kuat), begitu sebaliknya (Walpole 1992). Persamaan regresi yang dihasilkan digunakan untuk menentukan IPM tingkat kecamatan. Ini untuk menunjukan tingkat kesejahteraan masyarakat yang terdampak atau dipengaruhi kegiatan investasi berbasis lahan sehingga mengakibatkan suatu lanskap menjadi dinamis di setiap kecamatan.

\section{Membuat Peta IPM pada Tingkat Kecamatan}

Persamaan regresi yang didapatkan pada tingkat lanskap, dijadikan rumus dalam menentukan peta sebaran IPM berdasarkan CI tingkat kecamatan. Pembuatan peta menggunakan perangkat lunak ArcMap 10.4.1 dengan fungsi Spatial Analyst. Selanjutnya, peta yang dihasilkan dilakukan tumpang susun (overlay) dengan peta batas administrasi kecamatan dan peta sebaran konsesi perkebunan kelapa sawit, IUPHHK-HA, IUPHHK-HT dan pertambangan. Proses ini menghasilkan peta IPM per wilayah kecamatan. Setiap kecamatan akan memiliki nilai IPM yang menggambarkan kesejahteraan penduduknya. Informasi luas areal konsesi barbasis lahan pada setiap kecamatan menunjukan besarnya pengaruh penggunaan dan perubahan tutupan lahan untuk kegiatan pembangunan.

\section{Mengetahui Kondisi Iklim pada Lanskap}

Indikator iklim yang digunakan adalah suhu rata-rata pada lanskap. Suhu pada lanskap diukur oleh Badan Meteorologi, Klimatologi dan Geofisika (BMKG) secara terus menerus. Pada Lanskap ini, data suhu diukur di Bandar Udara Rahadi Oesman di Ketapang. Data suhu yang digunakan untuk mengukur perubahan suhu akibat dinamika lanskap adalah data suhu sebelum investasi berbasis lahan secara masif (tahun 1985 dan 1987). Kemudian suhu setelah investasi berbasis lahan masif yaitu suhu tahun 1990, 2000, 2010, dan 2018.

\section{HASIL DAN PEMBAHASAN}

\section{Dinamika lanskap kaitannya dengan kondisi Indeks Pembangunan Manusia (IPM)}

\section{Bobot Penutupan Lahan}

Peta tutupan lahan tahun 1990 memiliki 18 kelas tutupan, tahun 2000 memiliki 19 kelas tutupan, tahun 2010 terdapat 20 kelas tutupan, dan tahun 2018 terdapat 20 kelas tutupan. Pada 2000 tidak terdapat tutupan lahan berupa hutan tanaman $(\mathrm{Ht})$, karena ijin hutan tanaman industri (HTI) baru diberikan oleh Kementerian Lingkungan Hidup dan Kehutanan pada 2006 (KLHK 2017). 
Tabel 1. Bobot pengaruh manusia terhadap kelas tutupan lahan pada lanskap (Table 1. Score of human intervention to the landcover on the landscape)

\begin{tabular}{cccccccc}
\hline $\begin{array}{c}\text { Tutupan } \\
\text { lahan }\end{array}$ & Bobot & $\begin{array}{c}\text { Tutupan } \\
\text { lahan }\end{array}$ & Bobot & $\begin{array}{c}\text { Tutupan } \\
\text { lahan }\end{array}$ & Bobot & $\begin{array}{c}\text { Tutupan } \\
\text { lahan }\end{array}$ & Bobot \\
\hline $\mathrm{Hp}$ & 1 & $\mathrm{Hrs}$ & 6 & $\mathrm{Sw}$ & 11 & $\mathrm{Pk}$ & 16 \\
$\mathrm{~A}$ & 2 & $\mathrm{Rw}$ & 7 & $\mathrm{Br}$ & 12 & $\mathrm{~Tb}$ & 17 \\
$\mathrm{Hrp}$ & 3 & $\mathrm{~T}$ & 8 & $\mathrm{~B}$ & 13 & $\mathrm{Tm}$ & 18 \\
$\mathrm{Hs}$ & 4 & $\mathrm{Pt}$ & 9 & $\mathrm{Bdr}$ & 14 & $\mathrm{Tr}$ & 19 \\
$\mathrm{Hms}$ & 5 & $\mathrm{Pc}$ & 10 & $\mathrm{Ht}$ & 15 & $\mathrm{Pm}$ & 20 \\
\hline
\end{tabular}

Sumber: Pertimbangan para ahli tumbuhan, ahli penginderaan jauh, ahli ekologi, 2018.

Berdasarkan hasil wawancara dengan para ahli selanjutnya dilakukan kuantifikasi nilai bobot. Bobot tutupan lahan yang sangat dipengaruhi kegiatan manusia adalah Permukiman (Pm) sehingga diberikan skor 20, Hutan Tanaman (Ht) skornya 19, dan Perkebunan diberikan skor 16. Bobot Hutan Rawa Sekunder (Hrs) sebesar 6, yang didasari oleh kegiatan masyarakat banyak dilakukan di sekitar dan di dalam hutan ini (Meijaard et al. 2013). Hutan Primer (Hp) diberikan skor 1 karena interaksi manusia dengan hutan ini relatif kecil, dan rata-rata hutan ini memiliki akses yang sangat rendah, sehingga masyarakat kesulitan menjangkau hutan ini (Tabel 1).

\section{Analisis Dinamika Lanskap}

\section{Kabupaten Ketapang dan Kayong} Utara

Indeks dinamika lanskap (CI) dihasilkan dari analisis tutupan lahan tahun 1990, 2000, 2010, dan 2018 yang telah diberikan bobot pada setiap kelas tutupannya. CI yang dihasilkan yaitu CI 1990-2000, CI 2000-2010, dan CI 20102018. Metode yang digunakan adalah tumpang susun dan geostatistical analyst. Dinamika lanskap sangat dipengaruhi oleh besarnya investasi berbasis lahan, antara lain perkebunan kelapasawit, hutan tanaman industri dan pertambangan. Hasil analisis menunjukan pada periode 1990-2000 terdapat perubahan sebesar $28,7 \%$ atau seluas 988.555,2 $\mathrm{Ha}$, sedangkan area yang tidak berubah sebesar $71,29 \%$ atau seluas 2.455.211,1 Ha. CI kategori berubah pada periode 2000-2010 sebesar $13,8 \%$ atau seluas $473.461,9 \mathrm{Ha}$ dan yang tidak mengalami perubahan sebesar $86,3 \%$ atau seluas 2.970.304.4 Ha. Pada periode 2010-2018, sebesar $72,2 \%$ wilayah lanskap tidak mengalami perubahan, atau sekitar 2,5 juta $\mathrm{Ha}$, sedangkan CI yang mengalami perubahan sebesar $27,8 \%$ atau seluas 956.282,2 Ha (Tabel 2). Kemudian CI pada lanskap dilakukan tumpang susun dengan wilayah kecamatan, dan menghasilkan nilai CI setiap kecamatan. Hasil ini selanjutnya digunakan sebagai sumber analisis untuk mengetahui tingkat kesejahteraan masyarakat setiap kecamatan. 


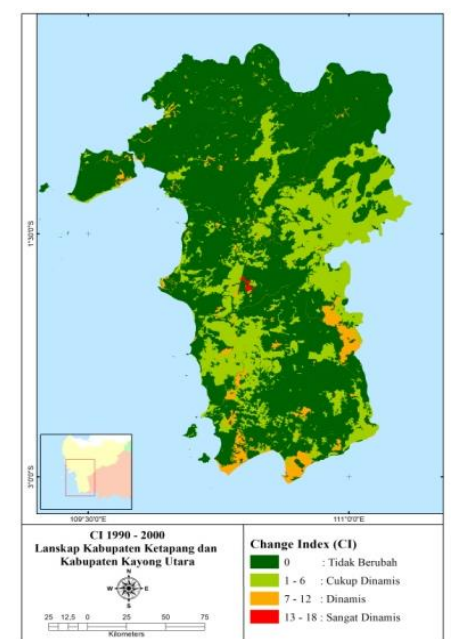

Gambar 1 Indeks

Dinamika (CI) lanskap periode 1990 - 2000

(Figure 1 Landscape

Change Index (CI) 19902000 period)

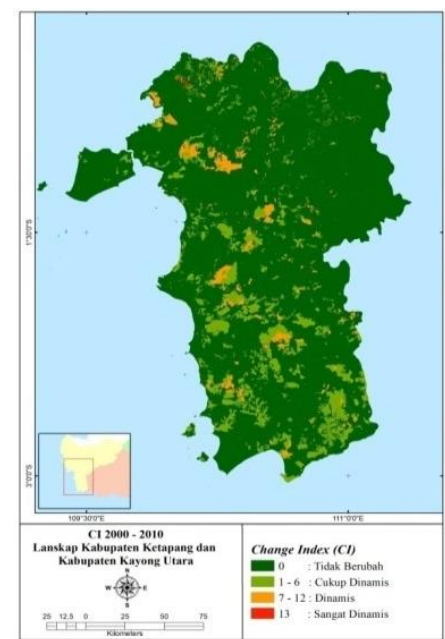

Gambar 2 Indeks

Dinamika (CI) lanskap

periode 2000-2010

(Figure 2 Landscape

Change Index (CI) 20002010 period)

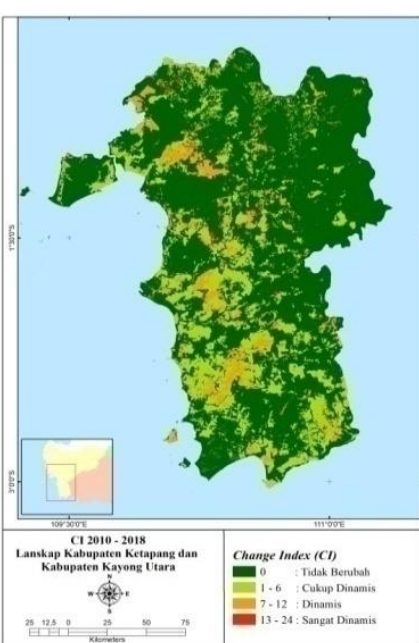

Gambar 3 Indeks

Dinamika (CI) lanskap

periode 2010-2018

(Figure 3 Landscape

Change Index (CI) 20102018 period)

Tabel 2. Dinamika lanskap periode 1990-2000, 2000- 2010, dan 2010-2018 (Table 2. Landscape dynamic on 1990-2000, 2000-2010 and 2010-2018 period

\begin{tabular}{|c|c|c|c|c|c|c|c|}
\hline \multirow{2}{*}{$\begin{array}{c}\text { Change } \\
\text { Index (CI) }\end{array}$} & \multirow{2}{*}{$\begin{array}{c}\text { Tingkat } \\
\text { kedinamisan } \\
\text { lanskap } \\
\end{array}$} & \multicolumn{2}{|c|}{$1990-2000$} & \multicolumn{2}{|c|}{$2000-2010$} & \multicolumn{2}{|c|}{$2010-2018$} \\
\hline & & Luas (ha) & $\%$ & Luas (ha) & $\%$ & Luas (ha) & $\%$ \\
\hline 0 & Tidak Berubah & $2.455 .211,1$ & 71,3 & $2.970 .304,4$ & $\overline{86,3}$ & $2.487 .484,1$ & 72,2 \\
\hline $1-6$ & Cukup Dinamis & $846.338,8$ & 24,6 & $363.826,2$ & 10,6 & $708.901,4$ & 20,6 \\
\hline $7-12$ & Dinamis & $139.275,5$ & 4,0 & $108.270,2$ & 3,1 & $238,478,3$ & 6,9 \\
\hline$>13$ & Sangat Dinamis & $2.940,9$ & 0,1 & $1.365,5$ & 0,0 & $8.902,5$ & 0,3 \\
\hline \multicolumn{2}{|c|}{ Luas Total } & $3.443 .766,3$ & & $3.443 .766,3$ & & $3.443 .766,3$ & \\
\hline
\end{tabular}

Sumber: Analisis data 2019

Luas investasi berbasis lahan pada lanskap untuk konsesi perkebunan kelapa sawit tahun 2018 seluas 455.120,0 Ha atau 36,0\% dari luas perkebunan kelapa sawit propinsi Kalimantan Barat (BPS 2018). Luas lahan untuk hutan tanaman seluas $750.854,4 \mathrm{Ha}$ atau 21,8\% dari luas lanskap (KLHK 2017), dan untuk pertambangan seluas 348.918,4 Ha, sedangkan luas pertambangan di Propinsi Kalimantan Barat 1.283.475,9 Ha atau sebesar 27,2\% (ESDM 2018).
Indeks Pembangunan Manusia (IPM) pada lanskap

IPM merupakan cerminan dari proses pembangunan daerah yang memanfaatkan sumberdaya alam (UNDP 2018). IPM pada lanskap tahun 2000 sebesar 60,8\%, kemudian mengalami penurunan pada 2010 menjadi 58,2\% dan pada 2018 meningkat menjadi $64,7 \%$. Secara umum, IPM pada lanskap berada pada interval IPM 60-70\%, diketegorikan sedang. Jika dibandingkan dengan IPM tingkat propinsi pada tahun 2000 sebesar 
64,1\%, kemudian pada 2010 sebesar $62,0 \%$, dan pada 2018 sebesar 67,0\%, maka tingkat kesejahteraan masyarakat pada lanskap masih berada di bawah kondisi kesejahteraan propinsi (BPS 2019). Nilai IPM pada lanskap tahun 2000, 2010, dan 2018 ditambahkan ke dalam data spasial atau peta batas administrasi kabupaten atau batas landskap. Selanjutnya, untuk mendapatkan nilai IPM awal tingkat kecamatan dilakukan melakukan tumpang susun antara peta batas lanskap dengan batas administrasi kecamatan. Nilai IPM awal pada kecamatan sama dengan nilai IPM pada lanskap.

\section{Hubungan antara CI dan IPM}

Analisis regresi sederhana dilakukan terhadap 3 periode tingkat dinamika lanskap (CI) pada 26 wilayah kecamatan dan 3 periode IPM pada lanskap. Data yang digunakan adalah nilai IPM awal per kecamatan tahun 2000, 2010, dan 2018; dan peresentase (\%) luas CI per kecamatan (Lampiran). Hasilnya menunjukan nilai signifikansi sebesar <0,05. Ini menunjukan terdapat pengaruh yang signifikan antara CI terhadap IPM. Koefisien regresi (b) yang dihasilkan sebesar 0,086. Ini menunjukan setiap peningkatan CI sebesar $1 \%$ akan meningkatkan IPM sebesar $0,086 \%$. Sehingga persamaan regresi yang diperoleh adalah IPM = 60,103+0,086 CI. Pada uji korelasi spearman menunjukan koefisien korelasi $\left(\mathrm{r}^{2}\right)$ sebesar 0,794. Ini menunjukan bahwa terdapat hubungan positif yang signifikan antara CI dengan
IPM yangartinya semakin tinggi nilai CI maka IPM juga akan semakin tinggi.

\section{Peta IPM pada lanskap sampai dengan Tingkat Kecamatan}

Tingkat kesejahteraan masyarakat pada wilayah kecamatan diperoleh dengan menggunakan pendekatan nilai CI. Proses yang dilakukan yaitu analisis spasial dengan menggunakan persamaan regresi yang dihasilkan. Hasil analisis spasial ini berupa IPM tingkat kecamatan, yang nilainya dipengaruhi tingkat CI setiap kecamatan tersebut. Kecamatan yang memiliki IPM tertinggi pada 2000 sebesar $65,1 \%$ dengan nilai CI sebesar $57,9 \%$, sedangkan yang IPM nya terrendah sebesar $60,1 \%$ dengan nilai CI sebesar $0,1 \%$. Nilai CI tertinggi sebesar $57,9 \%$, dan yang terrendahsebesar $0,1 \%$.

Pada periode 2010 , kecamatan yang memiliki IPM tertinggi sebesar 63,2\% dan yang terrendah sebesar $60.1 \%$, sedangkan nilai CI tertinggi sebesar $33,3 \%$ dan yang terrendah sebesar $0,1 \%$. Kemudian, pada tahun 2018 IPM tertinggi sebesar $65,1 \%$, dan yang terrendah sebesar $60,7 \%$, sedangkan CI tertinggi sebesar $57,7 \%$ dan yang terrendah sebesar 7,6\%. Investasi berbasis lahan meningkat sejak tahun 2000, investasi untuk perkebunan kelapa sawit naik hingga 3 kali lipat dalam 18 tahun, pada periode 1990-2000 luasnya sebesar $4 \%$, naik menjadi $8 \%$ pada 2010 , dan pada 2018 menjadi $16 \%$ dari luas lanskap, sedangkan investasi berbasis lahan lainnya berupa hutan tanaman dan pertambangan kenaikannya kurang dari 1\% (Tabel 3. Lampiran) (Gambar 4). 


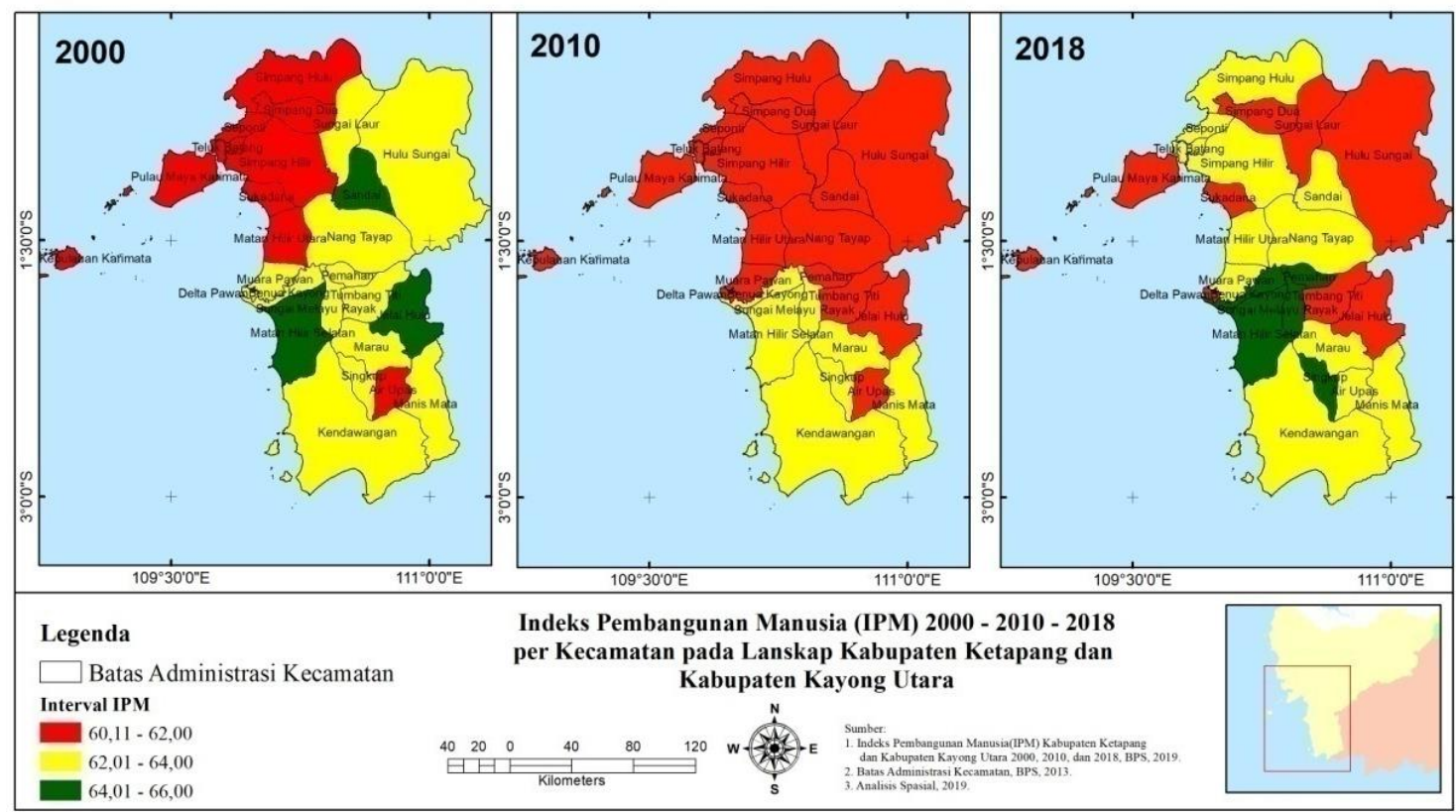

Gambar 4. Indeks Pembangunan Manusia (IPM) per kecamatan periode 2000, 2010, dan 2018

(Figure 4. Human Development Index (HDI) in each sub-district on 2000, 2010, and 2018 period)

Secara keseluruhan pada lanskap, kondisi IPM sangat dipengaruhi oleh nilai CI. Nilai CI merupakan hasil analisis spasial yang mengakomodir seluruh kondisi tutupan lahan pada lanskap. Peningkatan IPM pada lanskap yang diakibatkan oleh dinamika lanskap belum sepenuhnya menunjukan tingkat kesejahteraan sebagaimana yang diukur oleh BPS. Hal ini karena tingkat kenaikan IPM yang dipengaruhi oleh naiknya dinamika lanskap (CI) masih dalam tingkat IPM sedang yaitu antara 60-70\%. Jika dilihat dari luasnya areal yang dialokasikan untuk investasi berbasis lahan, kenaikan IPM masih sangat kecil, atau dapat dinyatakan tidak signifikan. Tahun 2018, alokasi perkebunan kebun kelapa sawit pada lanskap mencapai $75,71 \%$ dari luas areal penggunaan lain (APL), hanya tersisa $25 \%$ areal yang dapat dikelola oleh masyarakat dan pemerintah untuk keperluan pembangunan sektor lainnya. Jika kenaikan nilai CI sebesar $1 \%$ dapat meningkatkan nilai IPM sebesar 0,086\% maka untuk meningkatkan IPM menjadi kategori tinggi (70-80\%) maka diperlukan investasi lahan lebih luas. Kondisi ini dikhawatirkan berdampak pada kebutuhan konversikawasan hutan menjadi APL menjadi naik. Melihat fakta ini, diperlukan evaluasi pola bisnis perkebunan kelapa sawit dan investasi berbasis lahan lainnya yang dapat mendorong kesejahteraan masyarakat secara nyata pada tingkat kecamatan.

\section{Kondisi Iklim pada Lanskap}

Pada kurun 33 tahun sejak 19852018 kenaikan suhu mencapai $1,3^{\circ} \mathrm{C}$. Suhu rata-rata tahunan pada lanskap sejak 1985 hingga 2018 cenderung naik (Gambar 5). Pada 1985 suhu pada lanskap berkisar $26,4^{\circ} \mathrm{C}$, pada periode ini kondisi lanskap dalam kondisi belum terdapat kegiatan investasi berbasis 
lahan yang masif. Suhu rata-rata tahunan pada lanskap mengalami kenaikan pada tahun 1987 sebesar $0,5^{\circ} \mathrm{C}$ menjadi $26,9^{\circ} \mathrm{C}$. Pada periode 1987-1990, suhu lanskap mengalami penurunan sebesar $0,13^{\circ} \mathrm{C}$ menjadi $26,7^{\circ} \mathrm{C}$. Sejak 1985 1990 suhu lanskap naik sebesar $0,32^{\circ} \mathrm{C}$ pada level rata-rata $26,7^{\circ} \mathrm{C}$. Namun pada periode 1990-2018 suhu lanskap terus naik, dengan rata-rata kenaikan suhu per tahun selama 28 tahun sebesar $0,03^{\circ} \mathrm{C}$, menjadi $27,7^{\circ} \mathrm{C}$ pada 2018 atau naik sebesar $0,9^{\circ} \mathrm{C}$ (Tabel 4). Kenaikan suhu yang signifikan terjadi pada kurun 19902010, mencapai $0,7^{\circ} \mathrm{C}$. Hal ini terjadi karena kondisi lanskap mengalami proses dinamika yang sangat besar, nilainya mencapai $42,5 \%$ dari luas lanskap (Tabel 2). Perubahan lanskap dari matriks hutan menjadi lebih beragam mosaiknya menjadi salah satu faktor naiknya suhu pada lanskap.

Tabel 3. Suhu rata-rata tahunan pada lanskap tahun 1985, 1987, 1990, 2000, 2010, dan 2018 (Table 3. Annual temperature of the landscape 1985, 1987, 1990, 2000, 2010, and 2018)

\begin{tabular}{cc}
\hline Tahun & Suhu rata-rata $\left({ }^{\circ} \mathbf{C}\right)$ \\
\hline 1985 & 26,4 \\
1987 & 26,9 \\
1990 & 26,7 \\
2000 & 26,9 \\
2010 & 27,4 \\
2018 & 27,7 \\
\hline
\end{tabular}

${ }^{\circ} \mathrm{C}$

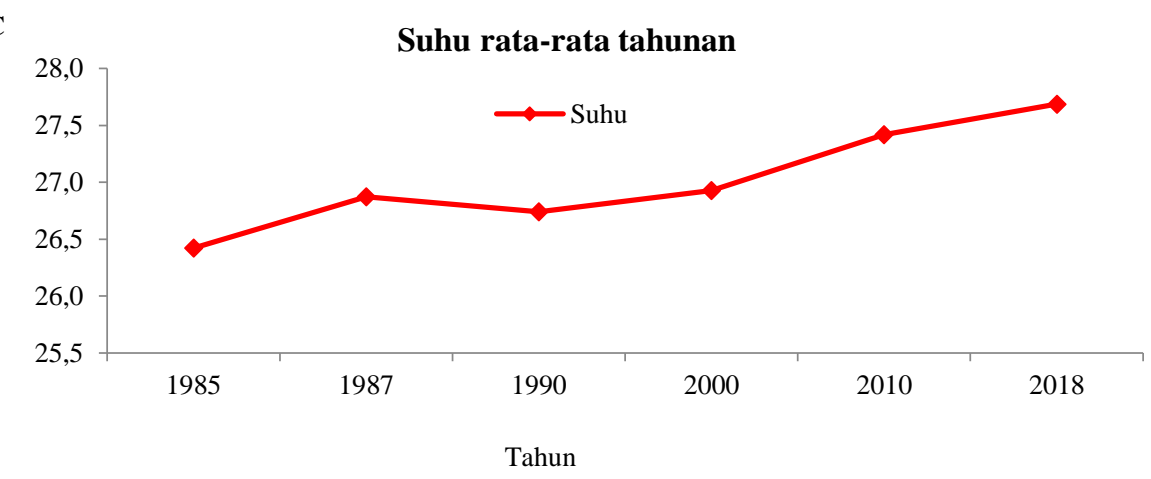

Gambar 5. Grafik suhu rata-rata tahunan 1985, 1987, 1990, 2000, 2010, dan 2018 pada lanskap (Figure 5. Annual temperature graph of the landscape in 1985, 1987, 1990, 2000, 2010, and 2018)

\section{KESIMPULAN}

Kondisi IPM tingkat kecamatan pada periode 1990-2018 dipengaruhi oleh tingkat dinamika lanskap nya, dengan rata-rata sebesar $62,7 \%$ pada 2018, naik dari 62,2\% pada tahun 2000 . CI naik dari $13,7 \%$ pada 2000 menjadi $33,9 \%$ pada 2018. Namun, kenaikan IPM ini belum mampu meningkatkan tingkat
IPM dari rendah (60-70\%) ke IPM sedang (70-80\%). Suhu pada lanskap dalam kurun 33 tahun mengalami kenaikan sebesar $1,27^{\circ} \mathrm{C}$. Periode sebelum investasi berbasis lahan masif dilakukan (sebelum 1990), suhu naik sebesar $0,32^{\circ} \mathrm{C}$, sedangkan pada periode 1990-2018, di mana investasi berbasis 
lahan sudah meningkat drastis dengan suhu meningkat sebesar $0,95^{\circ} \mathrm{C}$.

\section{SARAN}

Untuk meningkatkan kesejahteraan masyarakat, pemerataan pembangunan harus terus dilakukan. Investasi berbasis lahan pada lanskap belum dilakukan secara merata di setiap kecamatan, sehingga mempengaruhi kondisi tingkat kesejahteraannya. Pengukuran tingkat kesejahteraan dengan menggunakan indeks pembangunan manusia (IPM) harus dilakukan sampai tingkat kecamatan, untuk mengetahui pengaruh langsung dari investasi berbasis lahan.

\section{UCAPAN TERIMA KASIH}

Penulis mengucapkan terima kasih kepada thropenbos international yang telah memberi bantuan terhadap penelitian ini.

\section{DAFTAR PUSTAKA}

Agarwal C, Green GM, Grove JM, Evans TP, Schweik CM. 2002. A Review and Assessment of LandUse Change Models: Dynamics of Space, Time, and Human Choice. General Technical Report NE-297.

BPS. 2016. Indeks Pembangunan Manusia 2015: Badan Pusat Statistik.

BPS. 2018. Statistik Kelapa Sawit Indonesia 2017 in Perkebunan SST, ed: Badan Pusat Statistik.

BPS. 2019. Indeks Pembangunan manusia [diunduh 14]. Tersedia pada:

https://ipm.bps.go.id/page/ipm.

ESDM. 2018. Daftar Pemegang IUP Aktif Tahap Eksplorasi dan Operasi Produksi Provinsi Kalimantan Barat. Pontianak: Dinas Energi dan Sumber Daya Mineral.
Forman RTT, Gordon M. 1986. Landscape Ecology. New York: Wiley \& Sons, New York.

Käyhkö N, Skånes H. 2006. Change trajectories and key biotopesAssessing landscape dynamics and sustainability. Landscape and Urban Planning 75(3-4): 300321.doi:10.1016/j.landurbplan.20 05.02.011.

KLHK. 2014. Statistik Kehutanan 2014. Pusat Data dan Informasi. Jakarta, DKI Jakarta: Kementerian Lingkungan Hidup dan Kehutanan.

KLHK. 2017. Statistik Kehutanan 2016. Pusat Data dan Informasi. Jakarta, DKI Jakarta: Kementerian Lingkungan Hidup dan Kehutanan.

MacKinnon K, Hatta G, Halim H, Mangalik A. 1996. The Ecology Of Kalimantan Volume III. Periplus Editions.

Meijaard E, Abram NK, Wells JA, Pellier AS, Ancrenaz M, Gaveau DL, Runting RK, Mengersen K. 2013. People's perceptions about the importance of forests on Borneo. PLoS One 8(9): e73008.doi:10.1371/journal.pone. 0073008 .

Susilowati SH, Maulana M. 2016. Luas Lahan Usaha Tani dan Kesejateraan Petani: Eksistensi Petani Gurem dan Urgensi Kebijakan Reforma Agraria. Analisis Kebijakan Pertanian 10 (1): 17.doi:10.21082/akp.v10n1.2012. 17-30.

Turner MG, Romme WH, Gardner RH, O'Neill RV, Kratz aTK. 1993. A revised concept of landscape 
JURNAL TENGKAWANG (2020)

Vol. 10 (2): 109 - 122

equilibrium: Disturbance and stability on scaled landscapes. Landscape Ecology 8(3): 213 227.

UNDP. 2016. UNDP Human Development Reports.

UNDP. 2018. Human Development Indices and Indicators, 2018 Statistical Update in Programme UND, ed. New York: UNDP.

Walpole RE. 1992. Pengantar Statistika 3. Jakarta: PT. Gramedia Pustaka Utama.

Wood R, Handley J. 2001. Landscape Dynamics and the Management of Change. Landscape Research 26(1): 45-54.doi:10.1080/ 01426390120024475 . 
JURNAL TENGKAWANG (2020)

Vol. 10 (2): 109 - 122

\section{Lampiran 1}

Tabel 4. Model data Indeks Pembangunan Manusia (IPM) dan CI pada setiap kecamatan pada lanskap periode 2000, 2010, dan 2018 (Table 4. of data model of Human Development Index and CI in each sub-district of the landscape in 2000, 2010, and 2018 period)

\begin{tabular}{|c|c|c|c|c|c|c|c|c|c|c|c|}
\hline Tahun & KECAMATAN & $\begin{array}{c}\text { IPM } \\
\text { Awal } \\
(\%)\end{array}$ & $\begin{array}{c}\text { CI } \\
(\%)\end{array}$ & Tahun & KECAMATAN & $\begin{array}{l}\text { IPM } \\
\text { Awal } \\
(\%)\end{array}$ & $\begin{array}{c}\text { CI } \\
(\%)\end{array}$ & Tahun & KECAMATAN & $\begin{array}{c}\text { IPM } \\
\text { Awal } \\
(\%)\end{array}$ & $\underset{(\%)}{\text { CI }}$ \\
\hline 2000 & Air Upas & 60,8 & 9,0 & 2010 & Air Upas & 60,6 & 6,3 & 2018 & Air Upas & 66,8 & 25,1 \\
\hline 2000 & Benua Kayong & 60,8 & 32,4 & 2010 & Benua Kayong & 60,6 & 36,3 & 2018 & Benua Kayong & 66,8 & 52,1 \\
\hline 2000 & Delta Pawan & 60,8 & 32,4 & 2010 & Delta Pawan & 60,6 & 1,6 & 2018 & Delta Pawan & 66,8 & 12,0 \\
\hline 2000 & Hulu Sungai & 60,8 & 31,5 & 2010 & Hulu Sungai & 60,6 & 1,3 & 2018 & Hulu Sungai & 66,8 & 6,6 \\
\hline 2000 & Jelai Hulu & 60,8 & 57,9 & 2010 & Jelai Hulu & 60,6 & 8,9 & 2018 & Jelai Hulu & 66,8 & 14,3 \\
\hline 2000 & Kendawangan & 60,8 & 37,8 & 2010 & Kendawangan & 60,6 & 22,7 & 2018 & Kendawangan & 66,8 & 40,7 \\
\hline 2000 & Kep. Karimata & 60,8 & 0,1 & 2010 & Kep. Karimata & 55,8 & 0,1 & 2018 & Kep. Karimata & 62,6 & 7,6 \\
\hline 2000 & Manis Mata & 60,8 & 41,6 & 2010 & Manis Mata & 60,6 & 25,3 & 2018 & Manis Mata & 66,8 & 39,5 \\
\hline 2000 & Marau & 60,8 & 25,4 & 2010 & Marau & 60,6 & 33,3 & 2018 & Marau & 66,8 & 42,6 \\
\hline 2000 & Matan Hilir Selatan & 60,8 & 53,8 & 2010 & Matan Hilir Selatan & 60,6 & 24,5 & 2018 & Matan Hilir Selatan & 66,8 & 51,4 \\
\hline 2000 & Matan Hilir Utara & 60,8 & 11,2 & 2010 & Matan Hilir Utara & 60,6 & 15,8 & 2018 & Matan Hilir Utara & 66,8 & 33,9 \\
\hline 2000 & Muara Pawan & 60,8 & 25,2 & 2010 & Muara Pawan & 60,6 & 11,0 & 2018 & Muara Pawan & 66,8 & 39,7 \\
\hline 2000 & Nanga Tayap & 60,8 & 43,1 & 2010 & Nanga Tayap & 60,6 & 17,2 & 2018 & Nanga Tayap & 66,8 & 31,0 \\
\hline 2000 & Pemahan & 60,8 & 22,3 & 2010 & Pemahan & 60,6 & 4,4 & 2018 & Pemahan & 66,8 & 48,0 \\
\hline 2000 & P. Maya Karimata & 60,8 & 11,5 & 2010 & P. Maya Karimata & 55,8 & 3,6 & 2018 & P. Maya Karimata & 62,6 & 20,3 \\
\hline 2000 & Sandai & 60,8 & 48,6 & 2010 & Sandai & 60,6 & 7,1 & 2018 & Sandai & 66,8 & 23,2 \\
\hline 2000 & Seponti & 60,8 & 9,1 & 2010 & Seponti & 55,8 & 21,2 & 2018 & Seponti & 62,6 & 28,8 \\
\hline 2000 & Simpang Dua & 60,8 & 2,0 & 2010 & Simpang Dua & 60,6 & 5,4 & 2018 & Simpang Dua & 66,8 & 18,3 \\
\hline 2000 & Simpang Hilir & 60,8 & 5,7 & 2010 & Simpang Hilir & 55,8 & 18,0 & 2018 & Simpang Hilir & 62,6 & 32,1 \\
\hline 2000 & Simpang Hulu & 60,8 & 4,3 & 2010 & Simpang Hulu & 60,6 & 10,7 & 2018 & Simpang Hulu & 66,8 & 24,9 \\
\hline 2000 & Singkup & 60,8 & 34,0 & 2010 & Singkup & 60,6 & 27,9 & 2018 & Singkup & 66,8 & 50,1 \\
\hline 2000 & Sukadana & 60,8 & 7,1 & 2010 & Sukadana & 55,8 & 3,0 & 2018 & Sukadana & 62,6 & 8,7 \\
\hline 2000 & Sungai Laur & 60,8 & 22,9 & 2010 & Sungai Laur & 60,6 & 7,7 & 2018 & Sungai Laur & 66,8 & 19,6 \\
\hline 2000 & S. Melayu Rayak & 60,8 & 23,2 & 2010 & S. Melayu Rayak & 60,6 & 31,4 & 2018 & S. Melayu Rayak & 66,8 & 57,7 \\
\hline 2000 & Teluk Batang & 60,8 & 5,9 & 2010 & Teluk Batang & 55,8 & 0,6 & 2018 & Teluk Batang & 62,6 & 34,4 \\
\hline 2000 & Tumbang Titi & 60,8 & 22,5 & 2010 & Tumbang Titi & 60,6 & 8,3 & 2018 & Tumbang Titi & 66,8 & 20,2 \\
\hline
\end{tabular}

Sumber: Analisis 2019

Keterangan: S. : Sungai; Kep. : Kepulauan; P. : Pulau 
JURNAL TENGKAWANG (2020)

Vol. 10 (2): 109 - 122

\section{Lampiran 2}

Tabel 5. Kondisi Indeks Pembangunan Manusia (IPM), luas perkebunan kelapa sawit, hutan tanaman dan pertambangan tahun 2000, 2010, dan 2018 per kecamatan pada lanskap Kabupaten Ketapang dan Kabupaten Kayong Utara (Table 5. HDI value condition, Oil palm area, Logging plantation, and mining in each sub-district in 2000, 2010, and 2018 in Ketapang and Kayong Utara District landscape)

\begin{tabular}{|c|c|c|c|c|c|c|c|c|c|c|c|c|c|c|c|c|c|c|c|c|c|c|c|c|c|c|c|}
\hline \multirow{3}{*}{ No } & \multirow{3}{*}{ Kecamatan } & \multirow{3}{*}{$\begin{array}{l}\text { Luas } \\
\text { Wilayah } \\
\text { (Ha) }\end{array}$} & \multirow{2}{*}{\multicolumn{3}{|c|}{ IPM }} & \multicolumn{6}{|c|}{ Change Index (CI) } & \multicolumn{6}{|c|}{ Perkebunan KelapaSawit } & \multicolumn{4}{|c|}{ HutanTanaman } & \multicolumn{6}{|c|}{ Pertambangan } \\
\hline & & & & & & \multicolumn{2}{|c|}{$1990-2000$} & \multicolumn{2}{|c|}{$2000-2010$} & \multicolumn{2}{|c|}{$2010-2018$} & \multicolumn{2}{|c|}{2000} & \multicolumn{2}{|c|}{2010} & \multicolumn{2}{|l|}{2018} & \multicolumn{2}{|c|}{2010} & \multicolumn{2}{|c|}{2018} & \multicolumn{2}{|c|}{2000} & \multicolumn{2}{|c|}{2010} & \multicolumn{2}{|c|}{2018} \\
\hline & & & 2000 & 2010 & 2018 & $\mathrm{Ha}$ & $\%$ & $\mathrm{Ha}$ & $\%$ & $\mathrm{Ha}$ & $\%$ & $\mathrm{Ha}$ & $\%$ & $\mathrm{Ha}$ & $\%$ & $\mathrm{Ha}$ & $\%$ & $\mathrm{Ha}$ & $\%$ & $\mathrm{Ha}$ & $\%$ & $\mathrm{Ha}$ & $\%$ & $\mathrm{Ha}$ & $\%$ & $\mathrm{Ha}$ & $\%$ \\
\hline 1 & 2 & 3 & 4 & 5 & 6 & 7 & 8 & 9 & 10 & 11 & 12 & 13 & 14 & 15 & 16 & 17 & 18 & 19 & 20 & 21 & 22 & 23 & 24 & 25 & 26 & 27 & 29 \\
\hline 1 & Air Upas & $59.020,7$ & 60,9 & 60,6 & 62,3 & $5.318,9$ & 9,0 & $3.698,1$ & 8,9 & $19.006,2$ & 14,3 & $23.157,5$ & 39,2 & $26.663,4$ & 45,2 & $37.161,2$ & 63,0 & & & & & 101,2 & 0,2 & 101,2 & 0,2 & 353,7 & 0,6 \\
\hline 2 & Benua Kayong & $41.310,7$ & 62,9 & 63,2 & 64,6 & $13.368,6$ & 32,4 & $15.008,2$ & 22,8 & $209.150,5$ & 40,7 & & & $11.920,6$ & 28,9 & $18.456,8$ & 44,7 & & & & & & & & & 47,4 & 0,1 \\
\hline 3 & Delta Pawan & $6.342,5$ & 62,9 & 60,2 & 61,1 & $2.057,8$ & 32,4 & 100,0 & 0,1 & $1.895,5$ & 7,6 & & & & & & & & & & & & & & & & \\
\hline 4 & Hulu Sungai & $641.011,3$ & 62,8 & $3 \quad 60,2$ & 60,7 & $202.141,0$ & 31,5 & $8.026,4$ & 25,3 & $60.434,1$ & 39,5 & 640,7 & 0,1 & $1.215,0$ & 0,2 & $2.935,5$ & 0,5 & & & & & & & 28,6 & 0,0 & 41,7 & 0,0 \\
\hline 5 & Jelai Hulu & $133.193,9$ & 65,1 & 60,9 & 61,3 & $77.134,8$ & 57,9 & $11.821,2$ & 33,3 & $46.941,9$ & 42,6 & & & $4.856,5$ & 3,7 & $8.382,2$ & 6,3 & & & & & & & & & 32,6 & 0,0 \\
\hline 6 & Kendawangan & $513.540,7$ & 63,4 & $+62,1$ & 63,6 & $194.335,5$ & 37,8 & $116.817,5$ & 24,5 & $86.604,2$ & 51,4 & 92,2 & 0,0 & $27.360,9$ & 5,3 & $100.382,9$ & 19,6 & & & $5.950,4$ & 1,2 & 308,6 & 0,1 & 320,7 & 0,1 & $2.314,0$ & 0,5 \\
\hline 7 & Kepulauan Karimata & $24.975,7$ & 60,1 & 60,1 & 60,8 & 17,4 & 0,1 & 33,6 & 15,8 & $30.160,6$ & 33,9 & & & & & & & & & & & & & & & & \\
\hline 8 & Manis Mata & $152.917,8$ & 63,7 & $7 \quad 62,3$ & 63,5 & $63.608,6$ & 41,6 & $38.642,2$ & 11,0 & $21.028,5$ & 39,7 & $24.510,2$ & 16,0 & $46.476,2$ & 30,4 & $64.048,0$ & 41,9 & & & & & & & & & 53,3 & 0,0 \\
\hline 9 & Marau & $110.092,0$ & 62,3 & 63,0 & 63,8 & $28.001,6$ & 25,4 & $36.706,4$ & 17,2 & $79.175,3$ & 31,0 & $3.841,1$ & 3,5 & $29.149,6$ & 26,5 & $38.142,1$ & 34,7 & & & 816,3 & 0,7 & & & & & $1.538,0$ & 1,4 \\
\hline 10 & Matan Hilir Selatan & $168.497,9$ & 64,7 & 762,2 & 64,5 & $90.689,9$ & 53,8 & $41.249,6$ & 4,4 & $15.289,2$ & 48,0 & $1.127,7$ & 0,7 & $5.340,7$ & 3,2 & $15.538,1$ & 9,2 & & & $3.911,0$ & 2,3 & 257,4 & 0,2 & $11.075,1$ & 6,6 & $15.098,4$ & 8,9 \\
\hline 11 & Matan Hilir Utara & $88.954,6$ & 61,1 & 61,5 & 63,0 & $9.983,9$ & 11,2 & $14.064,7$ & 3,6 & $20.271,3$ & 20,3 & $5.867,5$ & 6,6 & $9.964,0$ & 11,2 & $21.531,9$ & 24,2 & & & & & & & & & & \\
\hline 12 & Muara Pawan & $53.014,7$ & 62,3 & 61,1 & 63,5 & $13.358,9$ & 25,2 & $5.853,4$ & 7,1 & $22.903,7$ & 23,2 & & & & & $7.765,8$ & 14,7 & & & & & & & & & & \\
\hline 13 & Nanga Tayap & $255.207,9$ & 63,8 & 61,6 & 62,8 & $110.007,3$ & 43,1 & $43.782,8$ & 21,2 & $10.108,3$ & 28,8 & & & $20.208,5$ & 7,9 & $49.651,8$ & 19,5 & & & & & & & & & 170,6 & 0 , \\
\hline 14 & Pemahan & $31.865,8$ & 62,0 & 60,5 & 64,2 & $7.095,0$ & 22,3 & $1.411,0$ & 5,4 & $15.498,9$ & 18,3 & $1.139,4$ & 3,6 & & & $12.111,1$ & 38,0 & & & & & & & & & & \\
\hline 15 & Pulau Maya Karimata & $100.035,8$ & 61,1 & 60,4 & 61,9 & $11.506,3$ & 11,5 & $3.569,5$ & 18,0 & $75.259,0$ & 32,1 & & & & & & & & & & & & & & & & \\
\hline 16 & Sandai & $98.620,5$ & 64,3 & 60,7 & 62,1 & $47.965,7$ & 48,6 & $7.029,5$ & 10,7 & $55.292,9$ & 24,9 & $1.883,3$ & 1,9 & $1.914,1$ & 1,9 & $17.204,0$ & 17,4 & & & & & & & 5,7 & 0,0 & 232,5 & 0, \\
\hline 17 & Seponti & $35.052,4$ & 60,9 & 61,9 & 62,6 & $3.189,1$ & 9,1 & $7.436,4$ & 27,9 & $24.915,6$ & 50,2 & & & $6.208,4$ & 17,7 & $7.890,2$ & 22,5 & & & & & & & & & & \\
\hline 18 & Simpang Dua & $84.698,2$ & 60,3 & $360,6^{\circ}$ & 61,7 & $1.707,5$ & 2,0 & $4.560,7$ & 3,0 & $3.911,4$ & 8,7 & & & & & $3.138,7$ & 3,7 & & & & & & & & & & \\
\hline 19 & Simpang Hilir & $234.356,3$ & 60,6 & $5 \quad 61,7$ & 62,9 & $13.251,6$ & 5,6 & $42.070,4$ & 7,7 & $26.195,6$ & 19,6 & $16.004,4$ & 6,8 & $39.630,9$ & 16,9 & $48.408,5$ & 20,7 & & & & & & & & & & \\
\hline 20 & Simpang Hulu & $221.808,6$ & 60,5 & 561,0 & 62,3 & $9.579,9$ & 4,3 & $23.789,2$ & 31,4 & $26.616,6$ & 57,7 & & & 252,6 & 0,1 & $17.395,3$ & 7,8 & $3.515,5$ & 1,6 & $9.993,8$ & 4,5 & & & $1.637,6$ & 0,7 & $3.078,3$ & 1,4 \\
\hline 21 & Singkup & $49.685,7$ & 63,0 & 62,5 & 64,4 & $16.871,4$ & 33,9 & $13.871,8$ & 0,6 & $7.303,5$ & 34,4 & $7.469,2$ & 15,0 & $15.488,2$ & 31,2 & $24.569,9$ & 49,5 & & & $2.291,0$ & 4,6 & & & & & 143,3 & 0,3 \\
\hline 22 & Sukadana & $45.024,7$ & 60,7 & 760,4 & 60,9 & $3.180,6$ & 7,1 & $1.336,7$ & 8,4 & $18.278,1$ & 20,2 & $2.523,1$ & 5,6 & $2.263,9$ & 5,0 & 653,1 & 1,5 & & & & & & & & & & \\
\hline 23 & Sungai Laur & $133.693,1$ & 62,1 & 160,8 & 61,8 & $30.626,5$ & 22,9 & $10.269,4$ & 8,9 & $19.006,2$ & 14,3 & $10.424,1$ & 7,8 & $11.442,7$ & 8,6 & $19.059,1$ & 14,3 & & & & & & & 168,1 & 0,1 & 302,8 & 0,2 \\
\hline 24 & Sungai Melayu Rayak & $46.102,2$ & 62,1 & 62,8 & 65,1 & $10.701,4$ & 23,2 & $14.493,0$ & 22,8 & $209.150,5$ & 40,7 & $2.616,1$ & 5,7 & $6.145,9$ & 13,3 & $14.827,7$ & 32,2 & & & & & 78,0 & 0,2 & $2.223,1$ & 4,8 & $3.015,5$ & 6,5 \\
\hline 25 & Teluk Batang & $21.260,4$ & 60,6 & 560,2 & 63,1 & $1.252,1$ & 5,9 & 122,7 & 0,1 & $1.895,5$ & 7,6 & $10.564,8$ & 49,7 & $10.564,8$ & 49,7 & $6.758,8$ & 31,8 & & & & & & & & & & \\
\hline 26 & Tumbang Titi & $90.570,7$ & 62,0 & 60,8 & 61,8 & $20.333,9$ & 22,5 & $7.559,5$ & 25,3 & $60.434,1$ & 39,5 & $23.157,5$ & & $3.513,3$ & 3,9 & $11.149,7$ & 12,3 & & & & & 155,0 & 0,2 & 157,6 & 0,2 & 155,6 & 0, \\
\hline
\end{tabular}

Sumber: Analisis data 2019 